\title{
A családorvoslás mint karrier. Orvostanhallgatók pályaválasztással kapcsolatos vélekedései és motivációi
}

\author{
[Dr. Mohos András ${ }^{1}$ | Prof. Dr. Varga Albert² I Markó-Kucsera Mária ${ }^{3}$ | Dr. Kalabay László ${ }^{4}$ I Dr. Torzsa \\ Péter $\left.{ }^{4}\right]$
}

1 levelező szerző 2 Szegedi Tudományegyetem, Általános Orvostudományi Kar, Családorvosi Intézet és Rendelő, Szeged 3 Szegedi Tudományegyetem, Általános Orvostudományi Kar, Népegészségtani Intézet, Szeged 4 Semmelweis Egyetem, Általános Orvostudományi Kar, Családorvosi Tanszék, Budapest

\section{Bevezetés}

Az erôs alapellátás a hatékony egészségügyi ellátórendszer egyik alappillére, mérhetô egészségnyereséget eredményez a társadalom számára [1, 2]. Fenntartása megfelelő számú és képzettségű humánerőforrást igényel, melynek biztosítása hazánkban és világszerte is komoly kihívás. A magyar egészségügy égető problémája a családorvosi praxisok kiüresedése, a betöltetlen praxisok nagy száma. Ebben szerepet játszik a családorvosok „elöregedése”, külföldi munkavállalása, a családorvosi pálya elhagyása. Míg az aktív családorvosok száma 6,6\%-kal csökkent az ezredforduló és 2015 között, az egy családorvos által ellátott éves betegszám átlagosan negyedével nőtt [3]. A családorvosok jelentős része 60 év feletti (38\%), a 40 év alatti orvosok aránya rendkívül alacsony (17\%). 2018. augusztus 1-jei adatok szerint 341 betöltetlen családorvosi praxis van Magyarországon. Ez az összes praxis több, mint 5\%-a [4].

A humánerőforrás-krízist jelenleg nem képesek megoldani a családorvosi képzésbe újonnan belépő kollégák. Egyre nehezebb a Családorvosi Tanszékek valamennyi rezidensi helyének betöltése, jelentős részük betöltetlen marad. A családorvosi rendszer fenntartásához, kellő utánpótlás biztosításához kulcskérdés a figyelemfelkeltés és a hallgatók motivációjának erősítése már a graduális képzés során. Világszerte számos tanulmány vizsgálta a hallgatói pályaválasztást befolyásoló tényezőket [5], azonban jelenleg nem rendelkezünk pontos képpel a hallgatók pályaválasztási motivációiról, döntési mechanizmusairól.

A vizsgálat célja az orvostanhallgatók családorvosi hivatással kapcsolatos ismereteinek felmérése, pályaválasztási motivációik elemzése, a pályaválasztást befolyásoló tényezők azonosítása.
Hipotéziseink:

1. Kevés orvostanhallgató érdeklődik a családorvosi pálya mint karrierlehetôség iránt.

2. A hallgatók kevés információval rendelkeznek a családorvosi hivatással kapcsolatban.

3. A családorvoslásnak kicsi a presztízse az orvostanhallgatók körében.

4. Megfelelő információátadással a családorvosi pálya presztízse és vonzereje növelhető.

A vizsgálat megállapításai a családorvostan szakvizsgával végezhető felnőtt családorvosi praxisbeli, illetve gyermek és felnőtt ellátással is foglalkozó, vegyes praxisbeli tevékenységre vonatkoznak. A gyermek családorvostan nem képezte részét a vizsgálatnak.

\section{Minta és módszerek}

Első felmérésünk 2016 őszén 94 negyed-, illetve ötödéves orvostanhallgató bevonásával, önkéntes, papír alapú kérdőíves adatgyűjtésen alapuló keresztmetszeti vizsgálat történt a Szegedi Tudományegyetem Általános Orvostudományi Karán (SZTE ÁOK). A negyedéves évfolyamból 60 fó töltötte ki a kérdőívet, az ötödéves évfolyamon 33 fó. A válaszadási arány $63,8 \%$ illetve $35,1 \%$ volt a két évfolyamon. A teljes mintában a férfiak száma 37 fó volt (39,4\%). Egyetlen kérdésben sem mutatkozott szignifikáns különbség az évfolyamok között, így a továbbiakban együtt elemeztük őket. A családorvoslás megítélését befolyásoló tényezők felmérésére egy -5-től +5-ig terjedő, 11 fokozatú skálát használtunk. Negatív pontszám a pálya vonzerejét csökkentő, míg a pozitív a vonzerőt növelő tényezőt jelent, az adott pontszám abszolút értéke pedig a hatás erősségére utal. A „0” azt jelentette, hogy az adott tényező nincs befolyással a 
családorvoslás megítélésére. A deskriptív megállapításokat követően logisztikus regressziós modellt alkalmaztunk a változók elemzésére, hiszen ebben az esetben az eredményt nem befolyásolja a független változók eloszlása, továbbá az esélyhányados számítás lehetősége mellett a valószínúségi tartományok is megadásra kerülhetnek. A mintában szereplő változók átlagának szignifikáns eltérésére t-próbát alkalmaztunk, a nominális bekategorizált változók elemzéséhez chi-négyzet próbát alkalmaztunk. Minden eljárás esetében 5 százalékos szignifikancia szintet határoztunk meg. Az elemzésekhez az IBM-SPSS 24 programot használtunk.

A második keresztmetszeti felmérésünket egy évvel később, 2017 szeptemberében végeztük el elsőés negyedéves orvostanhallgatók körében önkéntes, online kérdốivvel az SZTE ÁOK-n 78 fó részvételével. Az első évfolyamon 52 fó (23,6\%), a negyedik évfolyamon 26 fó $(14,1 \%)$ válaszolt a kérdéseinkre, a válaszadási arány $23,6 \%$ illetve $14,1 \%$ volt. A teljes mintában 38 fó volt férfi $(48,7 \%)$. Részben nyitott kérdéseket tartalmazó, strukturált kérdőívet alkalmaztunk. Tekintettel a kis elemszámra, statisztikai analízis nem készült, kizárólag tendenciák leírása történt.

A két kérdőív kitöltése különböző időszakban történt. A kitöltők között nem volt átfedés, így összességében négy különböző évfolyammal kapcsolatban, kétéves időszakot felölelve szereztünk információkat. Az első felmérés részletes kvantitatív elemzést tett lehetôvé, a többnyire nyitott kérdéseket tartalmazó második kérdőív pedig elősegítette a hallgatók véleményének részletesebb megismerését.

\section{Eredmények}

2016-ban a hallgatók 1\%-a válaszolta azt, hogy biztosan, 16\%-a, hogy valószínúleg családorvosként tervez dolgozni a jövőben, míg 37,2\% valószínűleg nem, $31,9 \%$ biztosan nem ezt a szakmát választaná, 12,8\%uk pedig még nem tudja, hogy milyen szakterületet szeretne választani. Sem az évfolyam, sem a nem tekintetében nem mutatkozott szignifikáns eltérés (1. ábra).

2017-ben az elsóévesek 3,9\%-a akart biztosan családorvos lenni, míg negyedévben ezt a választ senki nem jelölte meg. A „valószínúleg igen” válaszok aránya 15,4\%-ot és 19,2\%-ot tett ki. A „valószínúleg nem” $46,2 \%$-ot és 50\%-ot. A „biztosan nem” pedig 19,2\% és 3,9\% volt a két csoportban, míg a bizonytalanok aránya $15,4 \%$ és $26,9 \%$ volt (2. ábra).
1. ábra: Tervezi-e, hogy családorvosként dolgozik a jövöben? (2016)

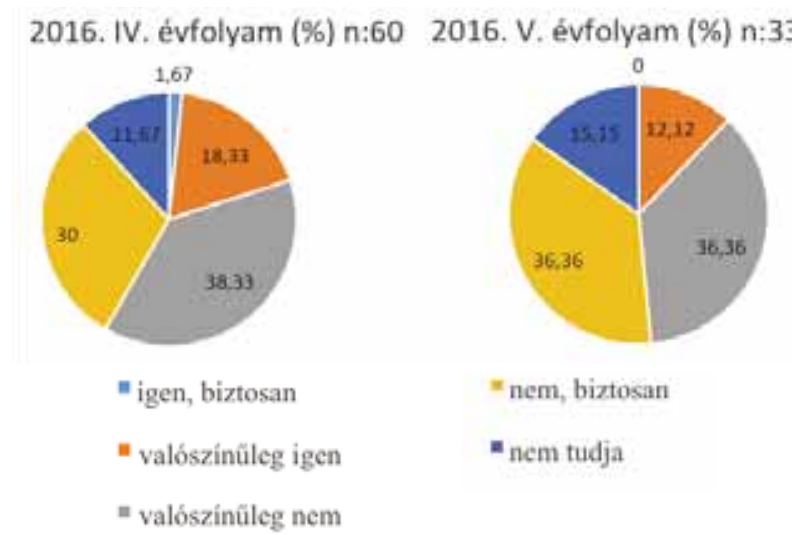

2. ábra: Tervezi-e, hogy családorvosként dolgozik a jövóben? (2017)

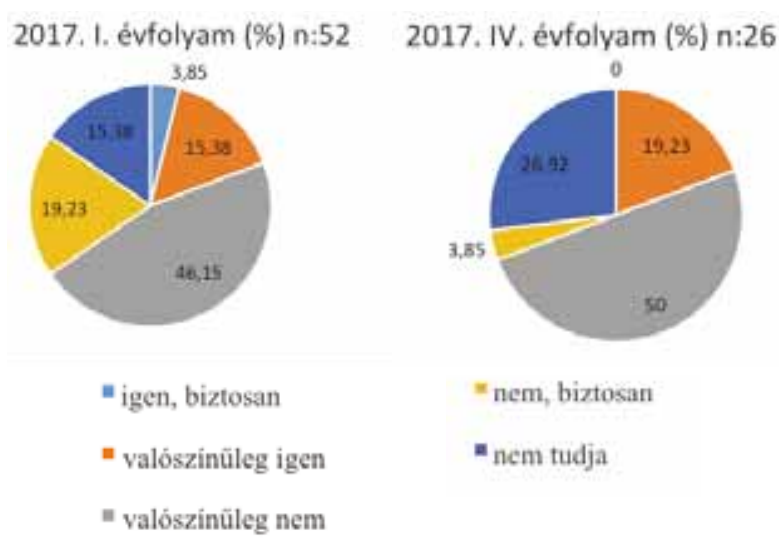

A bizonytalan hallgatók aránya több, mint 10\%-kal magasabb a negyedik évben, mint az elsőéveseknél, míg a családorvosi pályát elutasítók aránya ezzel fordított arányban változik. A hallgatók származási helye (1. táblázat) nem befolyásolta szignifikánsan sem a családorvosi pálya iránti érdeklődést $(\mathrm{p}=0,102)$ (CI 0,372-0,034), sem a vidéki, azaz nem Budapesten vagy egyéb városban történő, munkavállalás lehetőségét $(\mathrm{p}=0,152)$.

1. táblázat: A származási bely hatása a családorvosi pályaválasztásra (2016)

\begin{tabular}{l|c|c|c|c}
\hline \multirow{2}{*}{$\begin{array}{l}\text { Származási } \\
\text { bely }\end{array}$} & \multirow{2}{*}{$\begin{array}{c}\text { Hallgatók } \\
\text { száma }(f o ́)\end{array}$} & \multicolumn{3}{|c}{$\begin{array}{c}\text { Tervez családorvosként } \\
\text { dolgozni a jövóben? (fó) }\end{array}$} \\
\cline { 3 - 5 } & & Igen & Nem & Nem tudja \\
\hline Budapest & 17 & 4 & 13 & 0 \\
\hline Egyéb város & 64 & 11 & 44 & 9 \\
\hline Falu, egyéb & 11 & 1 & 2 & 8 \\
\hline
\end{tabular}

$(\mathrm{p}=0,102)(\mathrm{CI} 0,372-0,034)$

A szakellátásban történő elhelyezkedés esetén a hallgatók többsége városban dolgozna (főváros: 29\%, város: 45,2\%), 30,1\%-uk tervez külföldi munkaválla- 
lást. Családorvosként többen el tudják képzelni a falusi munkavállalást (28,2\%), és egyáltalán nem gondolkoznak külföldi munkavállalásban (3. ábra). A 2017-es kérdőívben az elsőéves hallgatók 7,7\%-a, a negyedévesek 26,9\%-a említette negatívumként a családorvoslás kapcsán a vidéki életmódot, magányt, elszigeteltséget.

3. ábra: Tervei szerint hol dolgozik majd az egyetem elvégzését követóen? (2016) (\%)
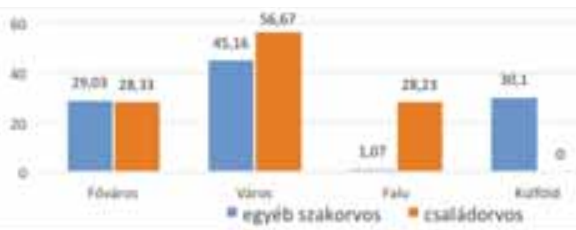

A családorvoslás graduális oktatásban történő bármilyen megjelenése pozitív irányba befolyásolja a pálya megítélését az orvostanhallgatók körében (0,425-1,32). Legjobban befolyásoló tényezők a családorvosi hivatásról szerzett ismeretek $(1,32)$ és a gyakorlati oktatás $(1,17)$, míg legkevésbé, de még szintén pozitív hatása van az elméleti oktatásnak (4. ábra).

4. ábra: Milyen mértékben befolyásolják az alábbi tényezók a családorvosi pálya iránti érdeklödést? (2016)

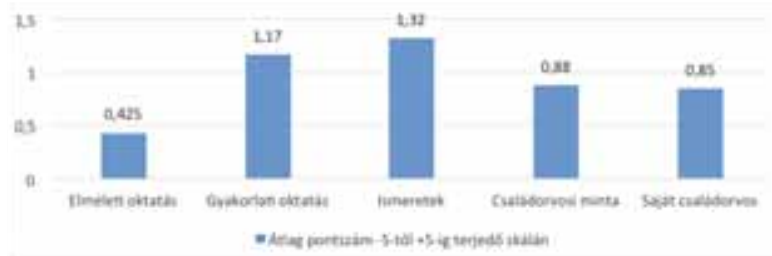

A hallgatók egészségüggyel kapcsolatos jelen és jövőképe, különösen a családorvosi pálya iránt érdeklődőké ( 2,2 vs. 1,$9 ; \mathrm{p}=0,027$ (CI 1,08-3,6) kifejezetten borús, ötfokozatú skálán a jelenlegi helyzet átlagpontszáma: 2,2, a jövőre mérsékelt optimizmussal tekintenek $(2,7)$ (5. ábra).

5. ábra: Milyennek itéli meg az egészségügy helyzetét? (fó) (2016)

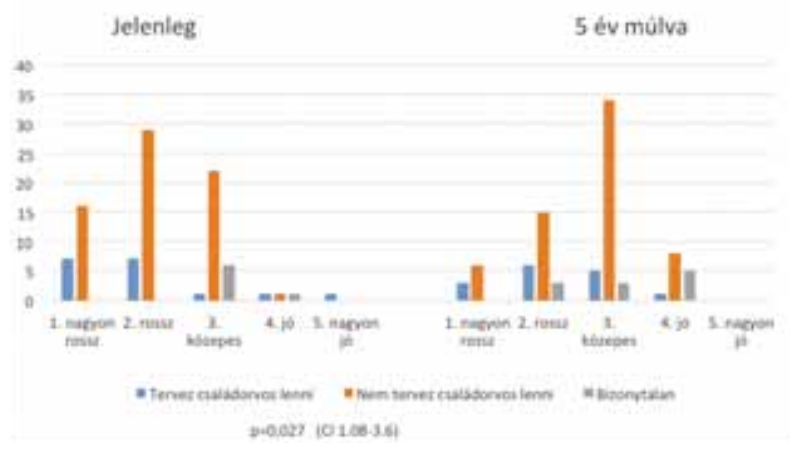

A családorvoslás presztízsét átlagosnak $(3,1)$, az orvostársadalmon belül inkább rossznak $(2,2)$ ítélik meg a hallgatók (6. ábra). Leendő havi nettó jövedelmüket 2016-ban a hallgatók 39,4\%-a 130 000-150 000 forint közé várta, 19,1\%-uk szerint ez kevesebb, mint 130000 forint lesz. A hallgatók 33\%-a szerint 150 000-300 000 forint lesz a jövedelmük, 6,4\% szerint 300000 forint felett. Arra a kérdésünkre, hogy „Ön hogyan látja, jövőbeni terveit tudja-e a várható jövedelmére alapozni?", a hallgatók 3,2\%-a biztosan igennel válaszolt, 29,8\%-uknak a véleménye valószínủleg igen, 35,1\%, valószínủleg nem, $21,3 \%$ biztosan nem, 10,6\% nem tudja. A két nem válaszai között nem volt szignifikáns különbség (7. ábra).

6. ábra: Ön szerint napjainkban milyen a családorvosok általános erkölcsi elismerése? (\%) (2016)

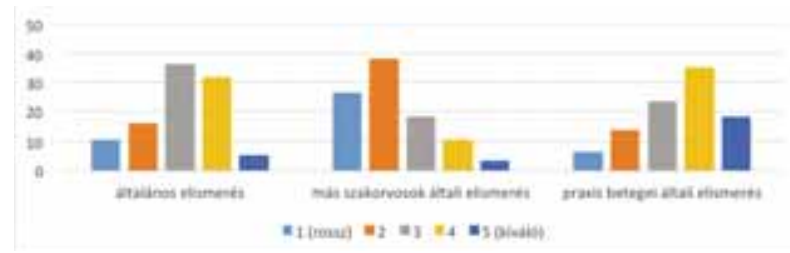

7. ábra: Ön hogyan látja, jövóbeni terveit tudja-e a várható jövedelmére alapozni? (\%) (2016)

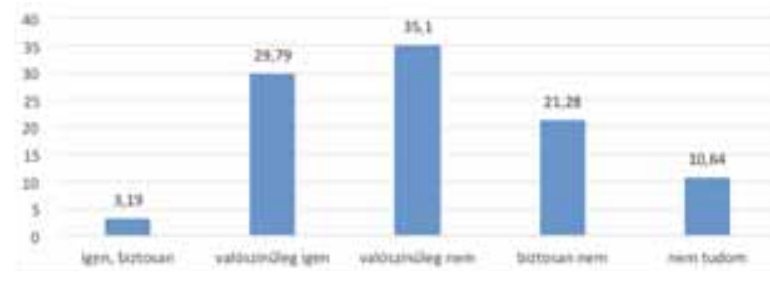

A második kérdőív válaszai alapján a hallgatók családorvoslásról alkotott képét legnagyobb mértékben a saját tapasztalataik (I. évfolyam: 56\%, IV. évfolyam: 58\%), a családorvosok tevékenysége (I. évfolyam: 64\%), és az egyetemi oktatás (IV. évfolyam: $38 \%)$ befolyásolják. A média az I. évfolyamosokat negatívan (21\%), míg a negyedéveseket alapvetően nem befolyásolja (38\%). A családorvosi pálya legvonzóbb elemeinek a sajátos orvos-beteg kapcsolatot (I.: 29\%, IV.: 19\%), a kedvező munkaidőt (I.: $27 \%$, IV.: 35\%) tekintik. Negatív vonásként a monotonitást (I., IV.: 46\%), az alacsony szintű szakmaiságot (I.: 13\%, IV.: 11\%.) és az alacsony presztízst (IV.: 15\%) jelölték meg. A pálya vonzóbbá tételében a hangsúlyosabb média, közéleti, illetve oktatásban történő megjelenés (I.: 37\%), a családorvoslás presztízsének növelése (IV.: 31\%) és a színvonalas munkavégzés (IV.: 39\%) játszhat leginkább szerepet. A IV. évfolyamos hallga- 
tók nem tértek ki a jövedelemre, I. éves társaik 7,7\%a kifejezetten vonzónak tartják a magas háziorvosi jövedelmet, míg 11,5\%-uk számára az alacsony jövedelem az egyik legkevésbé vonzó tényező. Az I. évfolyamos hallgatók 23,1\%-a úgy gondolja, a legmegfelelőbb módszer a családorvosi pálya vonzóbbá tételére a fizetésemelés lenne.

\section{Megbeszélés}

Vizsgálataink alapján megállapítható, hogy elenyésző azon hallgatók száma (0-3,8\%), akik kifejezetten a családorvosi pályára készülnek, míg sokan bizonytalanok a pályaválasztással kapcsolatban. Nemzetközi tanulmányokban széles skálán, 3,1\% és 36\% között mozog a családorvosi pálya iránt érdeklődő orvostanhallgatók aránya. A legtöbb felmérés szerint a hallgatók 15-20\%-a orientálódik ebbe az irányba [6-11]. Saját felmérésünk alapján a hallgatók mintegy 15-20\%-a tartja elképzelhetőnek, hogy családorvosként dolgozzon a jövőben. A Központi Statisztikai Hivatal (KSH) 2016-os adatai szerint a dolgozó orvosok 16,5\%-a dolgozott családorvosként, házi gyermekorvosként [3]. A fenti arányok fenntartásához arra lenne szükség, hogy valamennyi érdeklődő hallgató a családorvostan szakirányt válassza, majd családorvosként munkába is álljon, ennek azonban csekély a valószínúsége.

Az aktív családorvosok közel egyharmada vidéki praxisban tevékenykedik, így a vidéki családorvos utánpótlás biztosítása kiemelt jelentőségű. Ez azonban különösen nehéznek tűnik napjainkban. 2018. augusztus 1-jén 341, többnyire vidéki, tartósan betöltetlen családorvosi praxist tartottak nyilván, mely a hazai praxisok mintegy 5\%-át jelenti. Míg a budapesti, illetve városi családorvosok száma 1990 és 2014 között, 8,1\%-kal és 47\%-kal növekedett, addig a vidéken dolgozó családorvosok száma 26,2\%-kal csökkent [4]. Vizsgálatunkban a hallgatók többsége szintén a városi környezetet preferálja. Tanulmányunkban az is megfigyelhető, hogy a családorvosi munka kapcsán már többekben megfogalmazódik a vidéki munkavállalás gondolata, mintegy párhuzamot vonva a családorvoslás és a vidéki életmód között. A szakirodalmi adatok megoszlanak a vidéki származási helynek a későbbi vidéki munkavállalást befolyásoló szerepe kapcsán [12-16]. Vizsgálatunkban nem találtunk szignifikáns különbséget a két csoport között. A vidéki munkavállalás legerősebb pozitív prediktora a graduális, illetve a posztgraduális képzés során teljesített vidéki praxisgyakorlat [13-16]. Ennek ellenére jelenleg a graduális képzésben az országban sehol nem szerepel célzottan vidéki családorvosi gyakorlat. Állami szinten pályázati programokkal igyekeznek vonzóvá tenni a fiatal családorvosok számára a vidéki praxisokat. Fontosnak tartjuk, hogy már a graduális oktatás során megismerjék a hallgatók a vegyes praxisban dolgozó családorvos kollégák munkáját. 2017-ben 52 legalább egy éve betöltetlen praxis került betöltésre a letelepedési pályázat segítségével.

A hallgatói pályaválasztást befolyásoló, érdeklődésüket meghatározó tényezők megismerése lehetőséget ad a családorvosi pálya iránt fogékony hallgatókat azonosítására, hatékony pályaorientációs módszerek kifejlesztésére. A European Academy of Teachers in General Practice/Family Medicine (EURACT) által készített hallgatói attitűdváltozást vizsgáló kérdő́iv segítségével 93,5\%-ban előre jelezhető volt a hallgatók későbbi családorvosi pályaválasztása [17]. Több, ún. „belső” tulajdonság pályaválasztást befolyásoló szerepe is felvetődik, azonban hatásuk nem egyértelmú. A női nem egyes tanulmányokban növelte a családorvosi pályaválasztás esélyét [18]. Vizsgálatunkban, a korábbi tanulmányokhoz hasonlóan [6, 10, 19], a nem befolyásoló szerepe nem igazolódott. Szintén leírták a vidéki származás szerepét a családorvosi pálya iránti vonzódásban [20-22], de vizsgálatunkban nem találtunk ilyen összefüggést. A hallgatók életkorával, családi állapotával kapcsolatban szintén ellentmondásos elméletek léteznek, de jelen vizsgálatban ezek a változók nem rendelkeztek befolyásoló erővel. A hallgatók személyisége, érdeklődése szintén fontos a pályaválasztásban. A családorvosi pálya iránt vonzódó hallgatók jellemzően empatikusak, értékelik a hosszú távú orvos-beteg kapcsolatot, betegközpontúak. Fontos számukra a prevenció, a közösségi szemléletű gyógyítás [9, 10, 23]. Vizsgálatunkban a sajátos orvos-beteg kapcsolat és a változatos munka a hallgatók számára a legvonzóbb tényezők között szerepelt. Egyes szakmacsoportok iránt hasonló személyiségű hallgatók érdeklődnek, így a belgyógyászat, gyermekgyógyászat, családorvostan képez egy csoportot, míg az operatív szakmák iránt fogékony hallgatók családorvosi pálya iránti érdeklődésének felkeltése nehezebb feladat [8]. Olyan „belso”” jellemzőt, amely egyértelműen a családorvosi pálya választása ellen szólna, nem találtunk sem saját vizsgálatunkban, sem a szakirodalomban.

A hallgatók családorvoslással kapcsolatos ismereteit, attitűdjét ún. „külső tényezők” is befolyásolják. 
A különböző behatások már az egyetemi képzés előtt érik a leendő orvostanhallgatókat, majd az egyetemi évek alatt az oktatás révén, valamint azon kívül is. Ezek részben direkt, részben indirekt módon, az úgynevezett „rejtett tanterv” révén befolyásolják a hallgatókban kialakuló képet egy-egy szakterületről. Mivel az egyetemi oktatás erósen szakellátás-központú, az alapellátással kapcsolatos információkkal, szereplőkkel ritkán találkoznak közvetlenül a hallgatók. Vizsgálatunkból kiderül, hogy a hallgatók is érzik, hogy kevés, számos esetben pontatlan információval rendelkeznek a családorvosi pályáról. Ezeket az információkat részben saját tapasztalatokból, illetve ismerősöktől, valamint az egyetemi oktatás során szerzik. A pálya népszerüsitésének egyik leghatékonyabb módja szerintünk az egyetemi képzésben való hangsúlyosabb megjelenítés és részletesebb bemutatás. Vizsgálatunkból az is kiderült, hogy a hallgatók jelentős része a családorvoslást alacsony presztízsû́, kevés szakmai kihívást jelentő, valamint csekély szakmai előmenetelt kínáló specialitásnak tartja. Ezeknek az elképzeléseknek a kialakulásában sajnos jelentôs szereppel bír az egyéb szakterületen dolgozó orvoskollégák negatív véleménye is.

A borús helyzetértékelés nem pusztán a családorvosi pályára vonatkozik, hanem általánosságban az egészségügyre, az orvosi hivatásra is. Egy korábbi hazai tanulmányhoz hasonlóan a hallgatók többsége a jelen vizsgálatban is alábecsülte a várható jövedelmét [24]. 2018 nyarán a Markusovszky ösztöndíj igénybevételével több, mint nettó 280000 forint lehet a rezidensek havi bére. A válaszadók kevesebb, mint 16\%-a gondolta csak úgy, hogy legalább ekkora havi jövedelemre számíthat. Kifejezetten szomorú, hogy a hallgatók jelentôs része azzal a tudattal végzi a tanulmányait, hogy a hivatása nem biztosít számára majd megfelelő egzisztenciális hátteret.

Nemzetközi tanulmányok egybehangzó véleménye szerint a családorvosi pálya megismertetésének, ezáltal a pálya iránti érdeklődés felkeltésének leghatékonyabb módja a családorvostan oktatás beépítése a graduális képzésbe. Az információátadáson túl fontos szerepe van a negatív sztereotípiák lebontásában, az attitűd-formálásban [5, 10, 11]. Az EURACT 2013-as felmérése alapján 39 megkérdezett országból 11 ország 35 egyetemén (13,5\%) nincs családorvostan oktatás a graduális képzés során [25]. Az EURACT készített egy 15 fó témát tartalmazó központi tananyagot, melynek megvalósításához ajánlásokat is megfogalmaz [26]. A későbbi pályaválasztás szempontjából különösen a gyakorlatorientált okta- tás, valamint a családorvosi praxisgyakorlat bír jelentős hatással. Elmondható, hogy a gyakorlatok időtartama egyenes arányban áll a hallgatói attitűd általuk kiváltott pozitív változásával. Tekintettel a hallgatókat érô, sokszor negatív hatásokra, legideálisabb, az alapellátás megjelenítése az alapozó, a preklinikai, valamint a klinikai modulokban $[11,12,25,27]$. Vizsgálatunk eredményei a fentiekkel egybecsengenek.

A SZTE ÁOK-n a családorvostan nem kötelező tantárgy. Kötelezően választható kurzusként, alapvetôen tantermi előadás formájában teljesíthetik a hallgatók a klinikai modul során. A válaszokból látható, hogy a hallgatók véleményét bármilyen találkozás a családorvoslással, így a kurzuson való részvétel is, pozitívan befolyásolja. Annak ellenére, hogy az oktatás gyakorlati részével kevésbé elégedettek, mint az elmélettel, mégis jelentősebb mértékben befolyásolja pozitívan a családorvosi pályáról kialakított képüket. Ezek alapján feltételezhető, hogy a gyakorlati oktatás erősítésével kedvező változások érhetőek el a családorvosi hivatás megítélésében.

Vizsgálatunk igazolta az első hipotézisünket, azaz kevés orvostanhallgató érdeklődik a családorvosi pálya, mint karrierlehetôség iránt.

Második hipotézisünk is igazolást nyert, a hallgatók kevés információval rendelkeznek a családorvosi hivatással kapcsolatban.

Harmadik hipotézisünk is igazolódott, a családorvoslásnak alacsony a presztízse az orvostanhallgatók körében.

A vizsgálat igazolta a negyedik hipotézist, azaz megfelelő információátadással a családorvosi pálya presztízse és vonzereje növelhető.

Szakmai megfontolások alapján a családorvostan kurzus kötelezó tantárgyként kell szerepeljen a klinikai modulban. A pálya bemutatását azonban már hamarabb érdemes elkezdeni, a hallgatókat az egyetem előtt, illetve az egyetem korai szakaszában érő hatások miatt. Fontos feladat a családorvosi pálya presztízsének növelése, értékeinek bemutatása. Sikeres kezdeményezés a Semmelweis Egyetemen a Bevezetés a klinikumba tárgy, melynek során a másodéves hallgatók egy féléven keresztül hetente háziorvosi praxisba járnak ki, betegeket vizsgálnak és tematikus képzésben részesülnek [28].

Vizsgálatunk erőssége, hogy olyan aktuális témával foglalkozik, mellyel kapcsolatban a hazai szakirodalomban kevés információ áll rendelkezésre. A kérdốivek két különböző időszakot vizsgálnak, így kétéves időszakot felölelve, négy különböző évfolyam hallgatóiról szereztünk információkat. A második 
felmérés kérdéseit részben az első vizsgálat tanulságai alapján fejlesztettük tovább, így a két vizsgálat eredményei kiegészítik egymást.

A vizsgálat korlátai, hogy kizárólag a Szegedi Tudományegyetem orvostanhallgatói kerültek bevonásra, így az egész országra vonatkoztatható következtetések nem vonhatók le. Az alacsony részvételi arány miatt az eredmény nem reprezentatív. Az évfolyamok hallgatóinak 14,1-63,8\%-a vett részt a felmérésben, így a mintánk nem reprezentatív, de az eredmények összesítése nyomán született megállapítások az adott mintára érvényesek. A második adatfelvétel során a hallgatók személyes tájékoztatását követően, online juttattuk el számukra a kérdő́ivet, így csökkent a válaszadási arány. Feltehetőleg azok az orvostanhallgatók, akik egyáltalán nem érdeklődnek a családorvoslás iránt, részt sem vettek a vizsgálatban, így a családorvosi pálya iránt érdeklődők felülreprezentáltak lehetnek a mintában. A két kérdőív eltért egymástól, így a szerzett információk teljes körű összehasonlítására nem volt lehetőség.

Az ismertetett két „pilot vizsgálat” alapul szolgálhat egy nagyobb léptékú, az orvostanhallgatók családorvosi pályaválasztással kapcsolatos attitűdjét felmérő, valamennyi hazai orvosi egyetemre kiterjedő országos vizsgálat megvalósulásához.

\section{Összefoglalás}

Bevezetés: A magyar egészségügy égető problémája a családorvosi praxisok kiüresedése, a betöltetlen praxisok nagy száma. A humánerőforrás krízist jelenleg nem képesek megoldani a családorvosi képzésbe belépő új kollégák. Célunk az orvostanhallgatók családorvosi hivatással kapcsolatos ismereteinek, attitűdjének felmérése.

Minta és módszer: Önkitöltős kérdőívek segítségével végzett keresztmetszeti vizsgálat a Szegedi Tudományegyetemen, 2016-ban 94 fó, IV. és V. évfolyamos, 2017-ben 78 fó, I. és IV. évfolyamos orvostanhallgató körében.

Eredmények: 2016-ban a hallgatók 1\%-a biztosan, 16\%-a pedig valószínűleg családorvosként szeretne dolgozni a jövőben. 2017-ben az I. évfolyamon 3,9\% biztosan családorvos akart lenni, 15,4\% valószínúleg igen. A negyedik évfolyamon ez az arány 0\% és 19,2\% volt. A családorvoslás megjelenése a graduális képzésben pozitív irányban befolyásolta a pálya megítélését az orvostanhallgatók körében (átlagpontszám: 0,4-1,3. -5-tôl +5-ig terjedő, az egyes tényezők hatá- sának irányát és erôsségét jelző skálán). A családorvosi pálya iránt érdeklődők szignifikánsan rosszabbnak ítélték meg $(p=0,027)$ az egészségügy helyzetét. A pálya vonzóbbá tételében a hangsúlyosabb megjelenés a graduális képzésben (I. évfolyam: 37\%), a családorvoslás presztízsének növelése (IV. évfolyam: 31\%) és a színvonalas munkavégzés (IV. évfolyam: 39\%) játszhat leginkább szerepet.

Következtetések: Kevés orvostanhallgató készül családorvosi pályára. A családorvosi hivatás iránti érdeklődés felkeltésének leghatékonyabb módja a hallgatók ismereteinek növelése, melyhez kulcsfontosságú a családorvostan minél hangsúlyosabb megjelenítése a graduális képzésben.

Köszönetnyilvánítás: A kérdőívek orvostanhallgatókhoz való eljuttatásában Dr. Barabás Katalin és Dr. Kelemen Oguz nyújtott segítséget.

Kulcsszavak: családorvoslás, pályaválasztás, orvosképzés

\section{Irodalom}

1. The world health report 2008: primary care now more than ever. Switzerland: Geneva; 2008:13-22. http://www.who.int/whr/2008/whr08_en.pdf (Letöltés ideje: 2018.06.24.) Doi: nem ismert

2. Starfield B. Primary care: an increasingly important contributor to effectiveness, equity, and efficiency of health services. SESPAS report 2012. Gaceta Sanitaria 2012;26(s):20-26. https://pdfs.semanticscholar.org/fcee/caa6672dfa9f22b9c241e26dd23ebadc2e37.pdf (Letöltés ideje: 2018.06.24.) Doi:10.1016/j.gaceta. 2011.10.009

3. Central Statistical Office: Hungary 2016. [Központi Statisztikai Hivatal: Magyarország 2016.] KSH, Budapest 2017:93-94. http://www.ksh.hu/docs/hun/xftp/idoszaki/mo/mo2016.pdf [Hungarian] (Letöltés ideje: 2018.07.20.) Doi: nem ismert 4. Állami Egészségügyi Ellátó Központ: Tájékoztató A Tartósan Betöltetlen Háziorvosi Körzetekről

https://oali.aeek.hu/index.php/praxiskezelo-nyilvtartas/tartosan-betoltetlenkorzetek/95-tajekoztato-a-tartosan-betoeltetlen-haziorvosi-koerzetekrol\#tbhaziorvos (Letöltés ideje: 2018.08.22.) Doi: nem ismert

5. Turkeshi E, Michels N R, Hendrickx K, Remmen R. Impact of family medicine clerkships in undergraduate medical education: a systematic review. BMJ Open 2015;5:e008265. https://bmjopen.bmj.com/content/5/8/e008265.long (Letöltés ideje: 2018.06.10.) Doi:10.1136/bmjopen-2015-008265

6. Deutsch T, Lippmann S, Frese T, Sandholzer H. Who wants to become a general practitioner? Student and curriculum factors associated with choosing a GP career - a multivariable analysis with particular consideration of practice-orientated GP courses. Scandinavian Journal of Primary Health Care 2015;33:47-53. https://www.ncbi.nlm.nih.gov/pmc/articles/PMC4377739/pdf/pri-33-47.pdf (Letöltés ideje: 2018.06.10.) Doi: 10.3109/02813432.2015.1020661

7. Mariolis A, Mihas C, Alevizos A, Gizlis V, Mariolis T, Marayiannis K, et al. General Practice as a career choice among undergraduate medical students in Greece. BMC Medical Education 2007;7:15. https://www.ncbi.nlm.nih.gov/pmc/articles/PMC1899489/pdf/1472-6920-7-15.pdf (Letöltés ideje: 2018.06.10.) Doi: $10.1186 / 1472-6920 / 7 / 15$

8. Naimer S, Press Y, Weissman C, Zisk-Rony RY, Weiss YG, Tandeter H. Medical students' perceptions of a career in family medicine. Israel Journal of Health Policy Research 2018;7:1. https://www.ncbi.nlm.nih.gov/pmc/articles/PMC5808391/pdf/13584_2017_Article_193.pdf (Letöltés ideje: 2018.06.10.) Doi: 10.1186/s13584-017-0193-9

9. Ie K, Murata A, Tahara M, Komiyama M, Ichikawa S, Takemura YC, et al. What determines medical students' career preference for general practice residency training?: a multicenter survey in Japan. Asia Pacific Family Medicine 2018;17:2. 
https://apfmj.biomedcentral.com/track/pdf/10.1186/s12930-018-0039-9 (Letöltés ideje: 2018.06.10.) Doi: 10.1186/s12930-018-0039-9

10. Ster MP, Selic P. Intended Career Choice in Family Medicine in Slovenia: An Issue of Gender, Family Background or Empathic Attitudes in Final Year Medical Students? Mater Sociomed. 2017 Jun; 29(2): 143-148. https://www.ncbi.nlm.nihgov/pmc/articles/PMC5544448/pdf/MSM-29-143.pdf (Letöltés ideje: 2018.06.10.) Doi: $10.5455 / \mathrm{msm} .2017 .29 .143-148$

11. Nicholson S, Hastings AM, McKinley RK. Influences on students' career decisions concerning general practice: a focus group study. Br J Gen Pract 2016;DOI:10.3399/bjgp16X687049 https://bjgp.org/content/66/651/e768.long (Letöltés ideje: 2018.06.10.) Doi: 10.3399/bjgp16X687049

12. Walker JH, DeWitt DE, Pallant JF, Cunningham CE. Rural origin plus a rural clinical school placement is a significant predictor of medical students' intentions to practice rurally: a multi-university study. Rural and Remote Health 2012; 12:1908. [Online: available: http://www.rrh.org.au] (Letöltés ideje: 2018.06.10.) Doi: nem ismert

13. Dunbabin JS, McEwin K, Cameron I. Postgraduate medical placements in rural areas: their impact on the rural medical workforce. Rural and Remote Health 2006;6:481. [Online: available: http://www.rrh.deakin.edu.au] (Letöltés ideje: 2018.06.10.) Doi: nem ismert

14. Lewis MJ, Ellis R, Adusumilli SK, Cameron I. Twenty-five years on: outcomes of a longitudinal evaluation of the NSW Rural Resident Medical Officer Cadetship Program. Rural and Remote Health 2016;16:3846. [Online: available: http://www.rrh.org.au] (Letöltés ideje: 2018.06.10.) Doi: nem ismert 15. Jamieson JL, Kernahan J, Calam B, Sivertz KS. One program, multiple training sites: does site of family medicine training influence professional practice location? Rural and Remote Health 2013;13: 2496. [Online: available: http://www.rrh.org.au] (Letöltés ideje: 2017.11.16.) Doi: nem ismert 16. Straume K, Shaw DMP. Internship at the ends of the earth - a way to recruite physicians? Rural and Remote Health 2010;10:1366. [Online: available: http://www.rrh.org.au] (Letöltés ideje: 2017.11.16.) Doi: nem ismert

17. Šter MP, Švab I, Klemenc-Ketiš Z, Kersnik J. Development and validation of a questionnaire for evaluation of students' attitudes towards family medicine. Coll Antropol. 2015;39(1):1-10. https://pdfs.semanticscholar.org/ec8b/ea203004e99568c2804e09905f1c5b5f6bb2.pdf (Letöltés ideje: 2018.06.10.) Doi: nem ismert 18. Kruschinski C, Wiese B, Eberhard J, Hummers-Pradier E. Attitudes of medical students towards general practice: Effects of gender, a general practice clerkship and a modern curriculum. GMS Zeitschrift für Medizinische Ausbildung 2011;28(1). https://www.ncbi.nlm.nih.gov/pmc/articles/PMC3140385/pdf/ZMA28-16.pdf (Letöltés ideje: 2018.06.18.) Doi: 10.3205/zma000728

19. Deutsch T, Lippmann S, Heitzer M, Frese T, Sandholzer H. Choosing to become a general practitioner - What attracts and what deters? An analysis of German medical graduates' motives. J Family Med Prim Care 2016;5(1):34-41 https://www.ncbi.nlm.nih.gov/pmc/articles/PMC4943146/ (Letöltés ideje: 2018.06.10.) Doi: 10.4103/2249-4863.184620

20. Bunker J, Shadbolt N. Choosing general practice as a career - the influences of education and training. Aust Fam Physician 2009;38(5):341-4 https://www.racgp.org.au/download/Documents/AFP/2009/May/200905bunker .pdf (Letöltés ideje: 2018.06.10.) Doi: nem ismert

21. Laven G, Wilkinson D. Rural doctors and rural backgrounds: how strong is the evidence? A systematic review. Aust J Rural Health 2003;11(6): 277-284. https://www.ncbi.nlm.nih.gov/pubmed/14678410 (Letöltés ideje: 2018.06.21.) Doi: $10.1111 / j .1440-1584.2003 .00534 . x$

22. Viscomi M, Larkins S, Gupta TS. Recruitment and retention of general practitioners in rural Canada and Australia: a review of the literature. Can J Rural Med 2013;18(1): 13-23. https://srpc.ca/resources/Documents/CJRM/vol18n1/pg13.pdf (Letöltés ideje: 2018.06.21.) Doi: nem ismert

23. Kuikka L, Nevalainen MK, Sjöberg L, Salokekkilä P, Karppinen H, Torppa M, et al. The perceptions of a GP's work among fifth-year medical students in Helsinki, Finland. Scandinavian Journal of Primary Health Care 2012;30:2:121-126. https://www.ncbi.nlm.nih.gov/pmc/articles/PMC3378002/pdf/pri-30-121.pdf (Letöltés ideje: 2017.11.16.) Doi: 10.3109/02813432.2012.654194

24. Torzsa P, Csatlós D, Eőry A, Hargittay Cs, Horváth F, László A, et al. Hivatással és hálapénzzel kapcsolatos vélekedések a magyarországi családorvosok és családorvos rezidensek körében [Opinions of Hungarian family physicians and residents on vocation and informal payment]. Orv. Hetil., 2016;157(36):14381444. http://real.mtak.hu/39464/1/650.2016.30539.pdf (Letöltés ideje: 2017.01.14.) Doi: $10.1556 / 650.2016 .30539$

25. Brekke M, Carelli F, Zarbailov N, Javashvili G, Wilm S, Timonen M, et al. Undergraduate medical education in general pratice/family medicine throughout Europe - a descriptive study. BMC Medical Education 2013;13:157. https://bmcmededuc.biomedcentral.com/track/pdf/10.1186/1472-6920-13-157 (Letöltés ideje: 2017.11.16.) Doi:10.1186/1472-6920-13-157

26. Tandeter H, Carelli F, Timonen M, Javashvili G, Basak O, Wilm S, et al. A 'minimal core curriculum' for Family Medicine in undergraduate medical education: A European Delphi survey among EURACT representatives. European Journal of General Practice 2011;17:4:217-220. https://www.tandfonline.com/doi/pdf/10.3109/13814788.2011.585635?needAccess=true (Letöltés ideje: 2017.11.16.) Doi: 10.3109/13814788.2011.585635

27. Phillips J, Iain Charnley I. Third-and Fourth-Year Medical Students' Changing Views of Family Medicine. Fam Med 2016;48(1):54-60. http://www.stfm.org/Portals/49/Documents/FMPDF/FamilyMedicineVol48Issue 1Phillips54.pdf (Letöltés ideje: 2018.06.10.) Doi: nem ismert

28. Semmelweis Egyetem Általános Orvostudományi Kar Családorvosi Tanszék: Bevezetés a klinikumba. [Online: http://csot.semmelweis.hu/bevezetes-aklinikumba/] (Letöltés ideje: 2018.10.10.) Doi: nem ismert.

A cikk másodközlés. A cikk a szerzők és az első közlés lapjának engedélyével jelenik meg. Első megjelenése: Mobos A, Varga A, Markó-Kucsera M, Kalabay L, Torzsa P: A családorvoslás mint karrier. Orvostanhallgatók pályaválasztással kapcsolatos vélekedései és motivációi. [Family medicine as a career. Medical students' attitudes and vocational choice motivations] LAM 2019; 29 (12):627-634. https://doi.org/10.33616/lam.29.060. 